\title{
Keeping trainees safe in a pandemic: the evolving role of medical simulation training
}

\author{
Aaron Deng, BSc $\cdot$ Jessie J. Wang, BMLSc $\cdot$ Ban C. H. Tsui, MD, MSC, FRCPC
}

Received: 4 April 2020/Revised: 7 April 2020/Accepted: 8 April 2020/Published online: 20 April 2020

(c) Canadian Anesthesiologists' Society 2020

\section{To the Editor,}

The current global pandemic of coronavirus disease (COVID-19) has forced medical trainees throughout the world to suspend their clinical training and transition largely to online lectures. By removing trainees from clinical settings, medical programs hope to reduce the risk of person-to-person infectious spread. Nevertheless, as this unprecedented pandemic continues to develop, more trainees and healthcare providers (HCP) will be required to treat infected patients, and proper training will be key to protecting their safety. ${ }^{1}$ Fortunately, simulation-based medical education (SBME) is a quickly expanding tool within medical training that has made great advances in recent years. In particular, SBME has been lauded for its improvement of medical education, coupled with cost savings and protection of patients. ${ }^{2}$

According to the Federation of Medical Regulatory Authorities of Canada, final-year medical students in Canadian undergraduate medical programs have had their

\footnotetext{
A. Deng, BSc

Chicago Stritch School Medicine, Loyola University, Loyola

University Chicago, Maywood, IL, USA

Department of Anesthesiology, Perioperative, and Pain Medicine, Stanford University School of Medicine, Palo Alto, CA, USA

J. J. Wang, BMLSc

Faculty of Medicine, University of British Columbia,

Vancouver, BC, Canada

B. C. H. Tsui, MD, MSC, FRCPC ( $₫)$

Department of Anesthesiology, Perioperative, and Pain Medicine, Stanford University School of Medicine, Palo Alto, CA, USA

e-mail: bantsui@stanford.edu
}

board exams postponed because of the outbreak. ${ }^{\mathrm{A}}$ Although many of these students have been removed from their clinical electives until further notice, they will still be able to receive an educational license to enter any accepted residency position on schedule starting 1 July 2020. In the United States, governors in states that are COVID-19 hotspots have recently modified laws regarding medical trainees during this pandemic. ${ }^{\mathrm{B}, \mathrm{C}}$ These governors have suspended the usual record-keeping requirements, relaxing restrictions on practice for medical and nursing students and asking medical trainees to support the treatment of COVID-19 patients. Universally, this pandemic presents a learning opportunity for students and practicing HCP to improve the healthcare system's response to unprecedented public health concerns. Yet for students, COVID-19 also presents a unique health risk. With medical trainees being called upon to become more involved with COVID-19 care teams, the trade-off between education and HCP safety starts to blur. Despite use of personal protective equipment (PPE), COVID-19 has been

\footnotetext{
A Federation of Medical Regulatory Authorities of Canada. Licensing the 2020 Graduating Cohorts. Available from URL: https://fmrac.ca/licensing-the-2020-graduating-cohorts/ (accessed April 2020).

B Governor Andrew M. Cuomo. Executive Order No. 202.10: Continuing Temporary Suspension and Modification of Laws Relating to the Disaster Emergency. March 23, 2020, Albany, NY. Available from URL: https://www.governor.ny.gov/news/no-20210continuing-temporary-suspension-and-modification-laws-relatingdisaster-emergency (accessed April 2020).

C Office of Governor Gavin Newsom. Governor Newsom Announces California Health Corps, a Major Initiative to Expand Health Care Workforce to Fight COVID-19. Available from URL: https://www. gov.ca.gov/2020/03/30/governor-newsom-announces-californiahealth-corps-a-major-initiative-to-expand-health-care-workforce-tofight-covid-19/ (accessed April 2020).
} 
documented with asymptomatic human-to-human viral transmission, ${ }^{3}$ implicating high risk of infection for all HCP working with any patient, regardless of symptoms at the time.

One of the original intents of SBME was to provide students proper training without jeopardizing the care of patients in a critical condition. A recent study was published utilizing a simulation mannequin to analyze the effectiveness of PPE during the COVID-19 outbreak and to subsequently adjust PPE standards accordingly. ${ }^{4}$ From proper donning of PPE to patient management, simulation allows trainees to adhere to the public gathering bans being enforced by local governments and continue their medical education. This can be accomplished through eliminating human contact at simulation centres, remotely distributing virtual reality technology currently utilized in anatomy education, and/or integrating virtual simulation programs into online curricula. ${ }^{5}$

As incoming residents graduate with truncated clinical experiences, are they well-equipped to take on critical positions in high-risk areas of the hospital? While physicians are well-trained professionals, medical students find themselves in unfamiliar territory daily. Just as every medical student must learn how to avoid contamination of the sterile surgical field prior to entering the operating room, these incoming residents now require proper training to ensure their patients' safety and, equally important, their own. Whereas most SBME has been focused on teaching students the technical aspects of patient care and is traditionally used for code situations such as cardiac arrest or respiratory failure, its capacity to train HCP for their protection is seldom explored. Now, more than ever, it is critical that our medical schools and hospitals look to modern simulation practices to train our HCP not only on how to keep patients alive, but also on how to properly keep HCP themselves safe while working within this crisis.

Disclosures None.

Funding statement None.

Editorial responsibility This submission was handled by Dr. Hilary P. Grocott, Editor-in-Chief, Canadian Journal of Anesthesia.

\section{References}

1. Wax RS, Christian MD. Practical recommendations for critical care and anesthesiology teams caring for novel coronavirus (2019nCoV) patients. Can J Anesth 2020; DOI: https://doi.org/10.1007/ s12630-020-01591-x.

2. Issenberg SB, McGaghie WC, Petrusa ER, Gordon DL, Scalese RJ. Features and uses of high-fidelity medical simulations that lead to effective learning: a BEME systematic review. Med Teach 2005; 27: $10-28$

3. Bai Y, Yao L, Wei $T$, et al. Presumed asymptomatic carrier transmission of COVID-19. JAMA 2020; DOI: https://doi.org/10. 1001/jama.2020.2565.

4. Lockhart SL, Naidu JJ, Badh CS, Duggan LV. Simulation as a tool for assessing and evolving your current personal protective equipment: lessons learned during the coronavirus disease (COVID-19) pandemic. Can J Anesth 2020; DOI: https://doi.org/ 10.1007/s12630-020-01638-z.

5. Aebersold M. Simulation-based learning: no longer a novelty in undergraduate education. Online J Issues Nurs 2018; DOI: https:// doi.org/10.3912/OJIN.Vol23No02PPT39.

Publisher's Note Springer Nature remains neutral with regard to jurisdictional claims in published maps and institutional affiliations. 